\title{
The Ethnic Revival of Malay in The Governor Elections 2018 of West Kalimantan Province
}

\author{
${ }^{1}$ ALIF ALFI SYAHRIN, ${ }^{2}$ KARIM SURYADI, ${ }^{3}$ SITI KOMARIAH \\ 123 Universitas Pendidikan Indonesia, Jl. Dr. Setiabudi, Bandung, Indonesia \\ email: ${ }^{1}$ alifalfisyahrin@upi.edu
}

\begin{abstract}
Based on ethnicity, identity politics has become a political phenomenon, especially in the areas that have ethnic diversity such as in West Kalimantan Province. This study aims to explain the rise of Malay ethnic in the Governor Elections, 2018. In the last regional elections, there were differences in the growth of ethnic politics. This research used a qualitative approach through observation, interviews, and literature studies. The results show that the existence of a single contestant candidate from Malay ethnic that makes the votes become undivided. Next, there was an agreement from a tribal organization of Malays in the nomination of a candidate. Then, there was the distribution of controversial videos spoken by non-Malays who offend the Malay ethnic community. Soit makes the ethnic Malay united to win the pair of candidates Sutarmidji and Ria Norsan that have Malay ethnic background. For these reasons, it is a revival of ethnic politics in the ethnic Malay community.
\end{abstract}

Keywords: election, ethnic malay, west kalimantan province

\section{Introduction}

The holding of regional head elections (Pilkada) is part of the implementation of the democratic system. Indonesia is the thirdlargest country that adheres to a democratic system (Lewis, 2018). As expressed by Suryadi(2017: 75) that "democracy gives equal rights to all people to be elected to fill public positions. Democracy also gives freedom to the people to determine their leaders ".

The implementation of democracy in Indonesian is a decentralization system where regions get the right of regional autonomy. The regions are given the opportunity and power to regulate and manage their households (regional autonomy) called autonomous regions (Huda, 2012: 28). According to Arthur Maass (in Hendratno, 2009: 83) that "the distribution of power can be horizontally referred to as capital division of powers, While the vertical distribution of power is referred to as areal division of power. In the framework of the capital division of powers, each legislative, executive, and judicial function is given to an institution. In the areal division of powers, the functions like monetary and foreign relations are given to the central government, while other functions are given to the local government". The implementation of the regional head is to prevent money politics, which means bribing the masses of voters is far more difficult than giving dowry to DPR members (Suryadi, 2017: 148).

The regional head elections carried out in regions that have diversity often lead to a competition between ethnic community groups in winning the pair of candidates of governor and deputy governor. The Indonesian General Election Oversight Body (Bawaslu) has set the West Kalimantan province as the third most vulnerable province in the 2018 Regional Election Vulnerability Index because it is most likely "a campaign based on ethnic-religious sentiment (SARA), false accusations, deception, and deliberate efforts to divide voters based on ethnicity and religious lines (in Arifianto and Chen, 2018). According to Samuel Phillips Huntington (in Syaf, 2017) that "the rise of politics of civilization will mark global politics, domestic

Received: 2019-09-01, Revised: 2019-09-24, Accepted: 2019-12-25

Print ISSN: 0215-8175; Online ISSN: 2303-2499. DOI: https://doi.org/10.29313/mimbar.v35i2.5061

Accredited Sinta 2 based on the decree No.10/E/KPT/2019 until 2024. Indexed by DOAJ, Sinta, Garuda, Crossreff, Dimensions 
politics will bring up what he calls the rise of politics of ethnicity". Huntington stressed that the revival of ethnic politics would be strongly felt by the 'nation consisting of a diversity of nations,' ethnic and racial differences will be a source of new conflict within the State. Ethnic diversity has long been associated with adverse social consequences ranging from weaker social capital to greater conflict (Bazzi and Gudgeon, 2018).

Various kinds of social diversity in society are increasingly strengthened by the marginalization of one group of people that led to the emergence of identity politics, as revealed by Tornquist, (2009: 7) "the struggle for group solidarity on the other hand also contains efforts to promote inequality in civil rights in social, political and economic life".

Malays and Dayak in West Kalimantan Province are indigenous ethnicities (Peluso, 2008). Likewise, according to Ave and Victor (1986: 9), it said that "the majority of Malays in Kalimantan are descendants of the Dayaks who later converted to Islam". Most of Malay ethnic are more concentrated in coastal areas. It can be said that the Malay ethnic of West Kalimantan Province are Dayaks (indigenous) who have converted to Islam as revealed by Coomans (1987: 119) "for Dayaks to enter Malay" is synonymous with "converting to Islam." Dayaks who converted to Islam and thus became Malay (Jeremias, in Schulze, 2017). According to Hasan, (1999: 16) "The development of Catholic religion is generally in rural areas, as the development of Catholicism brought by the Jesuit Sarikat developed rapidly in Sejiram and later in Bika Kapuas Hulu, whereas in coastal areas it generally embraced Islam".

Ethnic politics is the use of ethnicity to influence political processes which are common in West Kalimantan. Dayaks and Malays, the two main ethnic groups in the province, have been in political competition since the days of Indonesian independence (Davidson, 2009; Tanasaldy, 2012). The competition has been sharper since the implementation of decentralization. The progress of decentralization, democratization, and direct election of political representatives at the local, regional, and national levels can lead to political empowerment in two ways: through the promotion of ethnicity as a political resource and the facilitation of wider political participation in a region and national level (Bräuchler, 2017). Not only within the scope of the Province of West Kalimantan, research conducted by Kristianus in 2016 with the research title "Politics and Ethnic Cultural Strategies in Simultaneous Local Election in West Kalimantan" states that in the simultaneous local elections in 2015 followed by 7 (seven) Regencies such as Ketapang, Sambas, Bengkayang, Sekadau, Melawi, Sintang, and Kapuas Hulu exhibited strong ethnicity symptoms between Dayak ethnic groups and Malay ethnic groups (Kristianus, 2016). According to Nordholt and Klinken (2007), since the 1999 Regent elections, there has been a power-sharing between Malays and Dayaks. Both ethnic groups succeeded in reaching an understanding of their respective territories. In a district that has a dominant ethnic group, the regent is from that ethnic group. It is what happened in Bengkayang and Landak which were dominated by Dayaks, and also in Sambas and Pontianak which were predominantly Malays. In districts with a balanced ethnic composition, for example in Ketapang and Kapuas Hulu, what is expected is mixed leadership.

In the 2018 Governor Election of West Kalimantan Province, there is competition between Malays and Dayak ethnic groups. The two ethnic groups are represented by two pairs of candidates for Governor and Deputy Governor: pair number 2 (two) Karolin Margret Natasha and Suryadman Gidot representing Dayak ethnic groups and pair number 3 (three) Sutarmidji and Ria Norsan representing Malay ethnic. In the Regional Election of West Kalimantan Province, there are dramatic religious exposures and ethnic divisions with the main axis of competition between Dayak Christians, Karolin Margret Natasha and Pontianak Mayor, Sutarmidji supported by the Islamic coalition (Power, 2018). Thus, there is inevitable competition between Malays and Dayaks in winning the 2018 Governor Election. If democratic procedures have given an opportunity for all parties to run for office, then voters have the freedom (free and secret) to choose one of them based on knowledge, beliefs and unanimous intention to bring improvement to all (Suryadi, 2017: 75).

In every implementation of the Governor's Election in West Kalimantan Province, it was found that there was competition between the two largest community groups in West Kalimantan Province. It is not wrong to say that a large mass creates political power. Both groups of people become crucial sources of votes if the pair of candidates for Governor and Deputy 
Governor are able to get the sympathy of each community group. It means that SARA issue, however, is inevitable in order to get support from every community group. In multi-ethnic societies, election campaigns can be a matter of debate. The effect on interethnic relations can be very acute because politicians' campaign methods often sharpen ethnic divisions, reduce elections to power struggles without victory and dominance between increasingly hostile ethnic groups (Fox, 2018). Not only in the 2018 elections, but also in the previous volume the issue of SARA played a part in getting votes. The condition is something unique in West Kalimantan Province. In the post-conflict local election, there are locality dimensions that cannot be forgotten so that there are no winning patterns that apply to all electoral districts (Suryadi, 2017: 123).

The Malay ethnic community is one of the majorities of ethnic groups in West Kalimantan Province. In 2000, the two largest ethnic groups were Dayaks and Malays, followed by Javanese, Chinese, Madurese, and Bugis (Tanasaldy, 2009). Malays ethnic lost two times in the 2007 governor's election and in 2012 candidates for Governor and Deputy Governor. Research conducted by Sri Astuti Buchari in 2014 entitled "Ethnic Awakening towards Political Identity" states that it was the revival of ethnic Dayaks in regional politics. This is evidenced by the success of the politics of identity of the Dayak ethnic group in the 2007 West Kalimantan Pilkada where they finally had their first Governor from their ethnic group after the New Order. The existence of marginalization and discrimination against ethnic Dayaks that occurred for decades caused the emotional ties of the ethnic Dayaks to be even tighter so as to bring up the identity politics of the Dayaks (Buchari, 2014).

In every election held by the Governor of West Kalimantan Province in 2007-2012, the political power of the Malay ethnic was not so optimal. It was, among others, because there was more than one pair of candidates for the Governor and Deputy Governor from the Malay ethnic group, causing the vote acquisition from each Regency which constitutes the majority ethnic Malay (coastal area) to be not optimal. However, in the implementation of the 2018 Pilkada, there were changes from the previous Pilkada. This paper attempts to explain the phenomenon that occurred in the 2018 Governor Election in the viewpoint of the revival of the Malay ethnic in the Governor Election so that it becomes an update from the previous research that covered the same theme. Based on what has been presented previously, this article focuses on the development of Malay ethnic politics in the direct Governor's Election of West Kalimantan Province since 2007, the Governor's Election in 2012, and the peak in the Governor's Election in 2018. There are various factors underlying the rise of Malay ethnic identity politics to peak in the 2018 Governor Election. The purpose of this article is to first explain the development of ethnic identity politics from the implementation of the Governor Election in 2007 to 2018, and the second explains the various factors forming the resurgence of Malay ethnic politics in the 2018 Governor Election in West Kalimantan Province.

\section{Research Methodology}

This study used a qualitative approach. In a qualitative approach, the researchers try to establish the meaning of a phenomenon from the view of the informants and identify various types of community groups and also learn how the group's behavior patterns develop over time (Creswell, 2014). In order to analyze various kinds of data obtained, researchers used a descriptive method. As expressed by Wolcott (1994) that "description is a qualitative representation that helps the reader see what you see and hear what you hear. Strong and descriptive foundations of your data allow a higher level of analysis and interpretation".

The techniques of this research are observation, interview, and literature study. The study was conducted in Sintang District because Sintang District has a tendency to be heterogeneous in terms of ethnic composition. Then, this study used in-depth interviews with 21 informants from each of the largest ethnic community groups in Sintang District such as Dayak ethnicity, Malay ethnicity, Chinese ethnicity, Javanese ethnicity, several local officials such as the Regent and Deputy Regent of Sintang Regency, and some tribal organization such as the Dayak Customary Council (DAD), the Malay Cultural Customary Council (MABM), the Chinese Traditional Cultural Council (MABT) and the Javanese Citizens' Community Center (Puspawaja).

Observations were made before the implementation of the 2018 Pilkada and after the elections. Observations were carried out directly in different periods. The areas were 
Pontianak City (conducted in 2017), Sambas District (conducted in 2018) and Sintang District (conducted in 2019). This research used literature studies and research data, for instance, vote acquisition data the Governor Election from 2007 until 2018 and also various previous studies relating to this research.

The data obtained were based on the formulation of the problem of Malay ethnic politics development since the Governor Election of 2007, 2012, and 2018. Data analysis in the study used data reduction, data display, and drawing the conclusions from the two research problem formulations. The validity test of the data in this paper used the extension of observation and triangulation. Triangulation is carried out in two forms: data source triangulation and technique triangulation. Data sources in this paper were the community of ethnic groups (Dayak Ethnics, Malay ethnic, Chinese and Javanese ethnic), figures of tribal organizations (DAD, MABM, MABT, and Puspawaja), and government officials (Regent of Sintang Regency, and Deputy Regent of Sintang Regency).

\section{Results and Discussion}

\section{The Development of Malay Ethnic Politics in West Kalimantan Provincial General Election in 2018}

According to Yusdianto, (2010: 44) "through the post-conflict local election, the people can choose who will be the leader and representative in the process of channeling aspirations which further determines the future direction of a country". The 2018 elections in West Kalimantan Province followed by 3 (three) pairs of candidates for Governor and Deputy Governor. The three pairs included pair number 1 (one) Milton Crosby and Boyman Harun, pair number 2 (two) Karolin Margret Natasha and Suryadman Gidot and pair number 3 (three) Sutarmidji and Ria Norsan. The three couples have political backgrounds in terms of serving as the regional head (Mayor, Regent, and Deputy Regent).

Table 1

Results of Vote Recapitulation of Governor and Deputy Governor Election of West Kalimantan Province in 2018

No $\begin{aligned} & \text { Pair of candidates } \\ & \text { for Governor and } \\ & \text { Deputy Governor }\end{aligned} \quad$ Voting Results

\begin{tabular}{lll}
\hline 1 & Milton Crosby - Boyman & $172.151(6,65 \%)$ \\
& Harun & \\
2 & $\begin{array}{l}\text { Karolin Margaret Natasa } \\
1.081 .878 \\
(41,79 \%)\end{array}$ \\
& - Suryadman Gidot & $\begin{array}{l}1.334 .512 \\
(51,55 \%)\end{array}$ \\
\hline
\end{tabular}

Source: Results of the Recapitulation Plenary Meeting of the General Election Commission (KPU) of West Kalimantan Province

Table 1 shows that the vote acquisition in the 2018 governor election in West Kalimantan Province was won by pair number 3 (three) totaling 1,334,512 votes, followed by pair number 2 (two) with $1,081,878$ votes and the pair number 1 (one) with 17,151 votes. The following vote is a detail of the number of votes obtained by each candidate pair in the 2018 elections of West Kalimantan Province based on each regency.

Table 2

Election Results in the West Kalimantan Province in 2018 based on each district

\begin{tabular}{llll}
\hline $\begin{array}{c}\text { Regency/ } \\
\text { City }\end{array}$ & $\begin{array}{c}\text { Milton- } \\
\text { Boyman } \\
(\mathbf{1})\end{array}$ & $\begin{array}{c}\text { Karolin- } \\
\text { Suryadman } \\
(\mathbf{2})\end{array}$ & $\begin{array}{c}\text { Sutarmidji- } \\
\text { Ria Norsan } \\
(\mathbf{3})\end{array}$ \\
\hline Landak & 6.361 & 218.968 & 20.634 \\
Melawi & 15.099 & 50.152 & 64.581 \\
Mempawah & 3.561 & 38.717 & 89.773 \\
Sambas & 9.093 & 53.264 & 227.315 \\
Sanggau & 24.568 & 151.450 & 63.080 \\
Sekadau & 22.480 & 52.087 & 34.316 \\
Sintang & 40.735 & 98.166 & 79.591 \\
Bengkayang & 3.817 & 87.365 & 33.682 \\
Kapuas Hulu & 6.051 & 59.204 & 63.814 \\
Kayong & 5.231 & 9.679 & 40.944 \\
Utara & & & \\
Ketapang & 14.366 & 87.241 & 125.140 \\
Kota & 4.809 & 73.100 & 239.135 \\
Pontianak & & & \\
Kota & 1.732 & 37.330 & 52.023 \\
Singkawang & & & \\
Kubu Raya & 4.248 & 65.155 & 200.484 \\
\hline Total & 172.151 & 1.081 .878 & 1.334 .512 \\
\hline Solat
\end{tabular}

Source: General Election Commission (KPU) of West Kalimantan Province in 2018

Based on table 2, the votes for pair number 3 (three) are concentrated in coastal areas such as Sambas Regency, Singkawang City, Mempawah Regency, Pontianak City, Kubu Raya Regency, Kayong Utara Regency and Ketapang Regency. The coastal area of West Kalimantan Province is predominantly Malay and Muslim. This is different from non-coastal areas such as Bengkayang Regency, Landak Regency, Sanggau Regency, 
Table 3

The 2012 Regional Head Election Results in West Kalimantan Province based on each district/city

\begin{tabular}{lcccc}
\hline \multicolumn{1}{c}{ Regency/City } & Cornelis-Christiandy & Armyn-Fathan & $\begin{array}{c}\text { Morkes- } \\
\text { Burhanudin }\end{array}$ & $\begin{array}{c}\text { Tambul- } \\
\text { Barnabas }\end{array}$ \\
\hline Kab. Sambas & 56.552 & 44.053 & 132.652 & 13.169 \\
Kab. Pontianak & 46.579 & 24.882 & 31.928 & 6.517 \\
Kab. Sanggau & 173.127 & 16.974 & 35.850 & 10.582 \\
Kab. Ketapang & 11.034 & 20.547 & 72.945 & 9.519 \\
Kab. Sintang & 120.906 & 14.686 & 68.251 & 10.895 \\
Kab. Kapuas Hulu & 54.573 & 7.686 & 11.709 & 54.701 \\
Kab. Bengkayang & 83.138 & 9.590 & 15.431 & 3.557 \\
Kab. Landak & 213.758 & 4.751 & 8.024 & 4.462 \\
Kab. Sekadau & 66.144 & 6.782 & 25.100 & 6.993 \\
Kab. Melawi & 64.446 & 8.298 & 39.656 & 8.931 \\
Kab. Kayong Utara & 11.504 & 7.651 & 18.343 & 3.642 \\
Kab. Kubu Raya & 84.603 & 57.675 & 65.167 & 22.121 \\
Kota Pontianak & 90.447 & 110.107 & 48.783 & 13.708 \\
Kota Singkawang & 48.374 & & & 3.219 \\
\hline Number of votes & 1.225 .185 & 28.062 & 17.242 & 172.016 \\
\hline
\end{tabular}

Source: General Election Commission (KPU) of West Kalimantan Province in 2012

Sekadau Regency, Sintang Regency, Melawi Regency, and Kapuas Hulu Regency which are predominantly Dayak ethnic community.

Thus, it can be said that in the 2018 elections, the pair number 3 was a representation of Malay ethnic and Muslims while in the pair number 2 is a representation of the Dayak ethnicity. This is stated by the competition for votes in each region which constitutes the majority of one ethnic group between ethnic Malays and Dayaks.

Table 3 shows the vote map for each candidate pair of Governor and Deputy Governor in the 2018 elections based on identity. In the 2012 elections, the vote acquisition of Malay ethnic or majority of Malay ethnic experienced divisions since there was more than one pair of candidates for Governor and Deputy Governor of ethnic Malay, for example, Morkes and Burhanuddin pair as candidates for the Governor and Deputy Governor of ethnic Malays who won in Sambas Regency and North Kayong Regency (coastal area). Likewise were Armyn and Fathan as candidates for Governor and Deputy Governor of ethnic Malays who won in the coastal area of Pontianak. Furthermore, the Tambul and Barnabas couples who were crossing between Malay and Dayak ethnic groups and won in Kapuas Hulu Regency. However, the cross pairing between Malay and Dayak ethnic groups was not too significant in boosting the votes. Cornelis and
Christiandy pair who were the candidates for the Governor and Deputy Governor of the Dayak ethnic and the Chinese ethnic group won in the Regency which was the majority of Dayak and Chinese ethnic areas such as Landak Regency, Sanggau Regency, Sintang Regency, Bengkayang Regency, Sekadau Regency, and Singkawang City.

Based on table 4, the first election of the Governor and Deputy Governor after the reforms were won by the Cornelis and Christiandy couples (Dayaks ethnic and Chinese) in areas that were the basis of Dayak and Chinese ethnic communities. As stated by La Ode (2012: 21) that the victory of the couple Cornelis and Christiandy is a combination of the voice of the ethnic Dayak and ethnic Chinese communities. While from other couples, especially the governor candidates from Malay ethnic and Dayaks, the votes were split like a cross pairing between Usman Ja'far and L. H Kadir, Oesman Sapta and Ignatius Lyong, and the pair of Akil Mochtar and Mecer in coastal and non-coastal areas.

Based on the elaboration of table 1 , table 2, table 3, and table 4, it was found that the vote acquisition map in the 2007 elections, the 2012 elections, and the 2018 elections had similarities based on the votes obtained between districts and cities in West Kalimantan Province. Coastal areas were areas of victory for governors and deputy governors 
Table 4

Result of Votes in West Kalimantan Province Election in 2007

\begin{tabular}{|c|c|c|c|}
\hline No & $\begin{array}{l}\text { Candidate Pair of Governor } \\
\text { and Deputy Governor }\end{array}$ & Votes & Victory Region \\
\hline 1. & Usman Ja'far and L. H Kadir & $659.279(30,94 \%)$ & $\begin{array}{l}\text { 1. Sambas Regency } \\
\text { 2. Pontianak Regency } \\
\text { 3. Pontianak City }\end{array}$ \\
\hline 2. & $\begin{array}{l}\text { Oesman SaptaOedang dan } \\
\text { Ignatius Lyong }\end{array}$ & $335.368(15,74 \%)$ & 1. Ketapang Regency \\
\hline 3. & Akil Mochtar and Mecer & $205.763(9,66 \%)$ & - \\
\hline 4. & $\begin{array}{l}\text { Cornelis and Christiandy } \\
\text { Sanjaya }\end{array}$ & $930.679(43,67 \%)$ & $\begin{array}{l}\text { 1. Landak Regency } \\
\text { 2. Kapuas Hulu Regency } \\
\text { 3. Sanggau Regency } \\
\text { 4. Sintang Regency } \\
\text { 5. Sekadau Regency } \\
\text { 6. Bengkayang Regency } \\
\text { 7. Melawi Regency } \\
\text { 8. Singkawang City }\end{array}$ \\
\hline
\end{tabular}

Source: Data has been processed by Zakina (2016)

candidates whose backgrounds were Muslim or Malay ethnic, while non-coastal areas are areas of victory for candidates who were nonMuslim such as Catholics or Christians or from Dayak ethnic backgrounds. From the third time implementation of the Governor Election in West Kalimantan Province, the map of the victory of the candidates for Governor and Deputy Governor based on identity (ethnicity and religion) can be predicted in the next election since the issue of identity is still so thick among the people.

\section{Factors Forming the Resurgence of Malay Ethnic politics \\ The Existence of a Single Pair of Malay Ethnic}

In the 2018 regional head elections in West Kalimantan, there was a single pair of Malay ethnic and Muslims, which was pair number 3 (three). This was different in 2007-2012. During the 2007 and 2012 local elections, there was more than one pair of candidates for governor and deputy governor who were Malay ethnic and Muslim. As a result, the vote acquisition in each of the coastal regencies was divided and not optimal, while coalition couples from Dayaks and Chinese ethnic got maximum votes in each district such as Singkawang and Pontianak which were the majority of Chinese ethnic; and Bengkayang Regency, Landak Regency, Sanggau Regency, Sekadau Regency, Sintang
Regency, Melawi Regency and Kapuas Regency Hulu which were the majority area of Dayak ethnic community.

The first thing in ethnic politics is to have an ethnic identity since ethnic politics are promoted based on ethnic identity, and it is exclusive (Xia, Lee, and Halim, 2018). At the local level, voters feel the consequences of the votes cast in the elections compared to national level elections (Tadjoeddin, 2012). This is due to the existence of a single pair of candidates for Governor and Deputy Governor of Malay ethnic utilized by the Malay community in optimizing votes for pair number 3. By looking at the history of the previous Pilkada (regional head election), the ethnic Malay community in the 2018 Pilkada united in winning the pair number 3 who represents Malay ethnic. Various kinds of policies that are felt to marginalize Malay ethnic communities are always remembered and culminated in the 2018 Governor Election. As revealed by Heywood, (2016, p. 532) "identity politics seeks to challenge and eliminate oppression by reshaping group identity through something that culminates in the process of political-cultural selfaffirmation."

In political participation, there is a model in understanding voting behavior in elections, including the sociology model. In this model, it is assumed that the behavior in the election is determined by the sociological characteristics of the voter, the main social 
class, religion, and ethnic group /locality/ language (Fuad, 2014). The Malay ethnic community feels they have ethnic similarity with the pair number 3 and decide to choose them. Cultural identity is the process by which members of a nation recognize, accept, and affirm their group's culture. Thus, a sense of belonging and further cultural awareness is ensured (Xiaomei and Shimin, 2014).

Joseph Schumpeter called the democratic method, (in Huntington, 1995, pp. 5-6) "proposing democracy as an institutional procedure for achieving political decisions in which individuals gain the power to make decisions through competitive struggles in order to gain popular votes." The 2018 Governor Election is the right moment to unite the votes to win the pair number 3 because in the previous Pilkada the vote acquisition of the Malay ethnic community was shared with other Malay ethnic pairs, causing defeat in the 2007 elections and the 2012 elections.

\section{An agreement of the Tribal Organization}

The agreements which are deliberated by tribal organizations are part of the effort to win one of the cadres or members in political competition. Efforts made by tribal organizations to produce nomination decisions are avoided as in the 2007 and 2012 elections. In both elections, the votes obtained by the pairs of governors and deputy governors of ethnic Malays were divided so that the vote acquisition from Malay ethnic groups was not maximized. However, in the 2018 elections, an agreement was made between the ethnic Malay figures to nominate one of the figures in order to avoid disunity in the Malay ethnic community.

Based on interviews with Malay ethnic community leaders in Sintang District, it was revealed that there was a decision to choose only one pair of the candidate from ethnic Malays competing in the 2018 Governor Election, West Kalimantan. However, based on reports from a number of media, the Malay tribal organization, that was the Malay Cultural Customary Assembly (MABM), did not declare itself to support the three pairs of candidates for Governor and Deputy Governor. There were only Malay tribal organizations other than MABM which explicitly provide full support to the pair number 3 (three), which was Malay Association (POM). As expressed by Goffman (in Lampe, 2010) that "when people interact, they will present a self-image that will be accepted by others". Prospective couples try to gain sympathy, especially in tribal organizations in West Kalimantan Province. As stated by Paskarina, Hermawati, and Nuraeni, (2019) figure-based politics and voluntary support actually play a greater role in the promotion of candidates. Hill and Wilson (2003) state that identity politics is "one of the ways we recommend looking at how culture and identity, which are variously perceived as traditional, modern, radical, local, regional, religious, gender, class, and ethnic, are articulated, constructed, created, and commodified as a means to achieve political goals ".

While tribal organizations other than ethnic Malays, such as the Dayak Customary Council (DAD), expressly supported pair number 2 because the candidate is a cadre of the Dayak Indigenous Council (DAD).

As it was reported, the tribal organization of Malays, the Malay Cultural Customary Council (MABM) of West Kalimantan Province, took a neutral decision in the 2018 governor election (Andilala, 2018). However, the organizational branch of the District level MABM, the Malay Cultural Customary Council of the Landak Regency, took a different side by supporting the pair number 2 (Habijan, 2018). As expressed by (Xue, 2018), candidates also try to exert influence on leaders and ethnic groups by offering materials or political commitment in return for the last support in the election.

Through decentralization, various parties have the right to get support and seek support, so that sometimes tribal organizations are involved in political practices that are not political parties. Competitive elections and decentralized governance have enabled various segments of Indonesian society to gain popular support in their efforts to gain power and access to government resources, at least at the local level (Choi, 2014).

\section{Circulation of Controversial Video}

Just before the voting day, there was a video circulating about the involvement of ethnic Malays and anarchists who marginalized ethnic Dayak groups. The thing that made the video into a scene was it was mentioned by the Dayak ethnic community leader who was the incumbent Governor (the period 2008-2013 and the period 2013-2018). Hence, it had an impact on the ethnic Malays 
in West Kalimantan with the circulation of controversial videos on Youtube and on social media networks in particular (Whatsapp, Facebook). Social media has given the power to influence society exclusively on social aspects (Damayanti and Hamzah, 2019).

The incident is similar to the case of Ahok (Governor of DKI Jakarta Province), which led to demonstrations among Muslims regarding a controversial speech (Mietzner and Muhtadi, 2018). Demonstrations carried out by Malay ethnic groups of Malay Association (POM) in Pontianak City on the celebration of the Dayak ethnic customary day (Gawai). As expressed by Erikson (in Maunati, 2004, p. 4), "ethnic or group identity will arise when the group or ethnicity is threatened".

Not only Malays who feel offended, but also Muslims since the video mentioned that Muslims in ancient times were also involved in the marginalization of the Dayak ethnic community. It drew strong reactions from Muslims that increasingly heating up social conditions. Ethnic mobilization in local elections sometimes risks creating political polarization based on ethnic lines and poses a real security threat to the community (Xue, 2018). As it is known Malay ethnic and Dayaks have a history of conflict between ethnic migrants (Schulze, 2017). It is important to note that ethnoreligious identity in West Kalimantan is very significant among Malays and Dayaks because local ethnic groups are interrelated with Islamic and Christian religions and within the framework of global interaction (Prasojo, 2017). Likewise, according to Vleming (in Hasanuddin and Kristanto, 2001), that "the religion of Islam is generally adhered to by the Malays, while animism is held by the Dayaks."

According to Castells (2010: 8), one of the factors that forming identity politics is resistance identity: a process of identity formation by social actors who are in a state of distress by the dominance and stereotyping by other parties - thus forming resistance and the emergence of a different identity from the party that dominates with the aim to the survival of the group. The Malay ethnic community felt pressured so that the emotional bond between the Malay ethnic was stronger than before. The peak, then, was occurred in the 2018 elections. However, it is inevitable that identity can also sow divisions among those who live side by side (Younge, 2018).

If it explores more deeply, there are similarities between the Malay ethnic and Dayaks in the phenomenon of the rise of identity politics between the two largest ethnicities in West Kalimantan Province. The existence of a marginalized assumption makes the emotional bond between the two ethnic groups become stronger. This was realized by the existence of identity politics as a form of resistance against marginalized groups. Thus, various kinds of division issues arise in the area of West Kalimantan Province. The division of administrative units has reduced tensions between several ethnic communities (Wilson, 2015) and benefit from the coalition of couples of various ethnicities and religions (Aspinall, 2011).

Therefore, the circulation of the speech video resulted in the Malay ethnic community and Muslims unite in winning the pair of candidates for Governor and Deputy Governor who came from the ethnic Malay and Islamic religions from those who had offended the ethnic Malay community groups and Muslims in West Kalimantan Province.

\section{Conclusions}

The Governor's Election in West Kalimantan Province since 2007 to 2018 applied the same pattern. First, it can be seen in the similarity of the map of the candidate victory of the Governor and the Deputy Governor based on the regions which constitute the majority of one community group. As in the coastal areas, the vote acquisition from among the ethnic Malay community seemed to be very significant towards the pair of candidates who were from ethnic Malay as well. The resurgence of Malay ethnic politics occurred in the 2018 governor election which was based on the existence of a single pair of candidates whose background was Malay ethnic and strengthened by the support of voters from the Muslim community and non-Malays such as Buginese, Javanese and so on. Second, there is an agreement from tribal organizations, especially Malay ethnic, in nominating their representatives to become candidates in the Governor Election, West Kalimantan, so that the votes among the Malays ethnic is not divided and maximal (in the coastal area). Third, there is a controversial video spoken by one of the Dayak ethnic community leaders who are also incumbent governors (2007-2012, 20132018) that makes Malay ethnic and Muslims unite to win the pair number 3 who represent ethnic Malays and Muslims. The need for a 
change of leadership from the representatives of the previous group which was felt to be controversial in West Kalimantan Province.

\section{References}

Andilala, A., S. (2018). MABM Kalbar tegaskan netral di pilkada (https:// kalbar.antaranews.com/berita/359796/ mabm-kalbar-tegaskan-netral-di-pilkada) diunduh pada 26 Agustus 2019.

Arifianto, A. R., \& Chen, R. (2018). Indonesia's 2018 Regional Elections West Kalimantan: Identity Politics at the Forefront. (RSIS Commentaries, No. 107). RSIS Commentaries. Singapore: Nanyang Technological University.

Aspinall, E. (2011). Democratization and Ethnic Politics in Indonesia: Nine Theses. Journal of East Asian Studies, Vol. 11, No. 2, pp. $289-319$.

Ave, Jan B. Victor T. King. (1986). "Borneo; The People of the Weeping Forest; Tradition and Change in Borneo". Leiden: National Museum of Ethnology.

Bazzi, S., Gudgeon, M. (2018). The political boundaries of ethnic divisions. NBER Working Paper no.24625.

Bräuchler, B. (2017). Changing Patterns Of Mobility, Citizenship, And Conflict In Indonesia. Social Identities, Vol. 23, No. 4, pp. 446-461.

Buchari, A. Sri. (2014). "Kebangkitan Etnis Menuju Politik Identitas". Jakarta: Yayasan Pustaka Obor Indonesia.

Castells, M. (2010). "The Power Of Identity". Oxford UK: Blackweel Publishing Ltd.

Choi, N. (2014). Local Political Elites in Indonesia: "Risers" and "Holdovers". Journal of Social Issues in Southeast Asia. Vol. 29, No. 2, pp. 364-407.

Coomans, M. (1987). "Manusia Dayak; Dulu, Sekarang, Masa Depan". Jakarta: Gramedia.

Creswell, J. W. (2014). "Research Design: Qualitative, Quantitative, And Mixed Methods Approaches". Thousand Oaks, CA: SAGE.

Damayanti, N. Hamzah, R. E. (2019). The Groundswell' Political Campaign Strategy of Anies-Sandi in the 2017 DKI Jakarta Governor Election, MIMBAR: Jurnal Sosial dan Pembangunan, Vol. 35, No. 1, pp. 28-37.

Davidson, J. S. (2009). "From Rebellion to Riots: Collective Violence on Indonesian Borneo". Madison, WI: University of Wisconsin Press.
Fox, C. (2018). Candidate-Centric Systems And The Politicization Of Ethnicity: Evidence From Indonesia, Democratization, Vol. 25, No.7, pp. 1190-1209.

Fuad, A. B. Barrul. (2014). Political Identity and Election in Indonesian Democracy: A Case Study in Karang Pandan Village Malang, Indonesia. Procedia Environmental Sciences, Vol. 20, pp. 477 - 485.

Habijan, Y. (2018). MABM Landak Dukung dan Siap Menangkan Karolin-Gidot (https:// www.suarakalbar.co.id/2018/06/mabmlandak-dukung-dan-siapmenangkan. html) diunduh pada 26 Agustus 2019

Hasan, S. (1999). "Dayak Muslim (Sejarah dan Perkembangannya)". Sintang: Sinamar Sintang.

Hasanuddin, Kristanto Budi. (2001). Proses Terbentuknya Heterogenitas Etnis di Pontianak Pada Abad Ke-19. Humaniora. Vol. 8, No. 1, pp. 64-81.

Hendratno, Toet. Edie. (2009). "Negara Kesatuan, Desentralisasi, Dan Federalisme". Yogyakarta: Graha IImu

Heywood, A. (2016). "Ideologi Politik (Sebuah Pengantar)". Yogyakarta: Pustaka Pelajar.

Hill, J. D. Wilson, T. M. (2003). Identity Politics and the Politics of Identities. Identities: Global Studies in Culture and Power, Vol.10, No.1, pp. 1-8.

Huda, N. (2012). "Hukum Pemerintahan Daerah". Bandung: Nusa Media.

Huntington, S. P. (1995). "Gelombang Demokrasi Ketiga". Jakarta: Pustaka Utama Grafiti.

Kristianus. (2016). Politik dan Strategi Budaya Etnik dalam Pilkada Serentak di Kalimantan Barat. Politik Indonesia: Indonesian Political Science Review, Vol. 1 , No.1, pp. 87-101.

La Ode, M. D. (2012). "Etnis Cina Indonesia Dalam Politik". Jakarta: Yayasan Pustaka Obor Indonesia.

Lampe, I. (2010). Identitas Etnik dalam Komunikasi Politik. Jurnal IImu Komunikasi, Vol. 8, No. 3, pp. $299-313$.

Lewis, B. D. (2018). Endogenous District Magnitude And Political Party Fragmentation In Subnational Indonesia: A Research Note, Electoral Studies, Vol. 55, pp. 136-145.

Maunati, Yekti. (2004). "Identitas Dayak (Komodifikasi dan Politik Kebudayaan)". Yogyakarta: LKiS.

Mietzner, Marcus. Muhtadi, Burhanuddin. (2018). Explaining the 2016 Islamist Mobilisation in Indonesia: Religious Intolerance, Militant Groups and the Politics of Accommodation, Asian Studies 
Review, Vol. 42, No.3, pp. 479-497.

Nordholt, H. S. Klinken, G. V. (2007). "Politik Lokal di Indonesia". Jakarta: Yayasan Pustaka Obor.

Paskarina, C. Hermawati, R. Nuraeni. (2019). Incumbency Advantage As A Basis Of Party Coalition In Regional Heads Candidate Selection, MIMBAR, Vol. 35 No. 1 , pp. $78-88$

Peluso, N. Lee. (2008). A Political Ecology Of Violence And Territory In West Kalimantan. Asia Pacific Viewpoint, Vol. 49, No. 1, pp. 48-67.

Power, P. Thomas. (2018). Jokowi's Authoritarian Turn And Indonesia's Democratic Decline, Bulletin of Indonesian Economic Studies, Vol. 54, No.3, pp. 307338.

Prasojo, Z. A. (2017). Social Change and the Contributions of the Tionghoa, Dayak and Melayu (Tidayu) in West Kalimantan. In Victor T. King, Zawawi Ibrahim \& Noor Hasharina Hassan (Eds.). Borneo Studies in History, Society and Culture. Singapore: Springer. pp. 427-442.

Schulze, K. E. (2017). The Ethnic In Indonesia's Communal Conflicts: Violence In Ambon, Poso, And Sambas, Ethnic and Racial Studies, Vol. 40, No. 12, pp. 2096-2114.

Suryadi, K. (2017). "Menak Senayan (Arsitek Komunikasi Politik Indonesia)". Bandung: Pustaka Jaya.

Syaf. Edi, J. (2017). Pertarungan Simbol Identitas Etnis Sebagai Komunikasi Politik Dalam Pilkada Kota Makassar. Jurnal Komunikasi KAREBA, Vol. 6, No.2.

Tadjoeddin, M. Z. (2012). Electoral Conflict And The Maturity Of Local Democracy In Indonesia: Testing The Modernisation Hypothesis, Journal of the Asia Pacific Economy, Vol. 17, No.3, pp. 476-497.

Tanasaldy, T. (2009). Ethnic geography in conflicts: the case of West Kalimantan, Indonesia, Review of Indonesian and
Malaysian Affairs, Vol. 43, No.2, pp. 105-30.

Tanasaldy, T. (2012). "Regime Change and Ethnic Politics in Indonesia: Dayak Politics of West Kalimantan". Leiden: KITLV Press.

Tornquist, O. (2009). "Introduction: The Problem is Representation". In O. Tornquist, N. Webster, \& K. Stokke (Eds.), Rethinking Popular Representation - Google Books. New York: Palgrave Macmillan.

Wilson, C. (2015). Illiberal democracy and violent conflict in contemporary Indonesia, Democratization, Vol. 22, No.7, pp. 13171337.

Wolcott, H. F. (1994). "Transforming qualitative data: Description, analysis, and interpretation". Thousand Oaks, CA: Sage.

Xia, N. Lee, Y. F. Halim, A. H. A (2018). The Elites' Collective Subjectivities Of The History Of Ethnic Politics In Malaysia, Asian Ethnicity, Vol. 20, No.2, pp. 168182.

Xiaomei, Z. Shimin, Wang. (2014) Political Identity: A Perspective from Cultural Identity, Social Sciences in China, Vol. 35, No. 2, Pp. 155-173.

Xue, S. (2018): Ethnic mobilization in 2015 local elections in North Sumatra, Indonesia, Asian Ethnicity, Vol. 19. No.4, pp. 509-527.

Younge, G. (2018). The Politics Of Identity: From Potential To Pitfalls, And Symbols To Substance, Identities, Vol. 26, No.1, pp. 1-11.

Yusdianto. (2010). Identifikasi Potensi Pelanggaran Pemilihan Kepala Daerah (Pemilukada) dan Mekanisme Penyelesaiannya. Jurnal Konstitusi, Vol. 2, No. 2,

Zakina. (2016). Politik Etnisitas Dan Compliance Gaining Kandidat Minoritas Dalam Pilkada Kalimantan Barat, Jurnal Komunikasi, Vol. 1, No.2, pp. 122-129. 